Marquette University

e-Publications@Marquette

Psychology Faculty Research and Publications

Psychology Department

$1-1-2016$

Maternal Attachment Buffers the Association Between Exposure to Violence and Youth Attitudes About Aggression

Jessica Houston

Marquette University, jessica.houston@marquette.edu

John H. Grych

Marquette University, john.grych@marquette.edu

Accepted version. Journal of Clinical Child \& Adolescent Psychology, Vol. 45, No. 5 (2016): 605-613.

DOI. (C) 2016 Taylor \& Francis (Routledge). Used with permission. 


\title{
Maternal Attachment Buffers the Association Between Exposure to Violence and Youth Attitudes About Aggression
}

\author{
Jessica Houston \\ Department of Psychology, Marquette University, \\ Milwaukee, WI \\ John Grych \\ Department of Psychology, Marquette University, \\ Milwaukee, WI
}

\begin{abstract}
The present study examined the relative and cumulative predictive power of parent-child, interparental, and community aggression on youths' perceptions of the acceptability of aggression between peers and siblings. The potential for mother-child attachment to buffer the effects of violence on aggressive attitudes was tested, as well as the link between aggressive attitudes and aggressive behaviors. A diverse sample of 148 children (ages 914) completed measures of interparental, parent-child, and community aggression; a measure of mother-child attachment quality; and a measure of aggressive behaviors. Participants also rated the acceptability of aggressive interactions between two peers and two siblings in written vignettes. Mothers completed a measure of their child's aggressive behaviors. Youths' violence exposure was related to perceptions of aggression as more acceptable, with

Journal of Clinical Child \& Adolescent Psychology, Vol 45, No. 5 (2016): pg. 605-613. DOI. This article is (C) Taylor \& Francis (Routledge) and permission has been granted for this version to appear in e-Publications@Marquette. Taylor \& Francis (Routledge) does not grant permission for this article to be further copied/distributed or hosted elsewhere without the express permission from Taylor \& Francis (Routledge).
\end{abstract}


parent-child aggression having the only unique association. Maternal attachment buffered the relation between exposure to community violence and perceived acceptability of aggression, which predicted decreased aggression. When exposed to high levels of community violence, youths with more secure maternal attachment perceived aggression as less acceptable than youths with less secure attachment and, in turn, displayed fewer aggressive behaviors. Interventions that focus on strengthening the caregiver-child relationship in children exposed to violence may reduce aggressive behaviors by interrupting the development of aggressive attitudes.

Violence is a major threat to children's and adolescents' health and development. It has been estimated that 30\%-50\% of children are exposed to community violence in their lifetime and about $19 \%$ are exposed to violence in the home (Finkelhor, Turner, Ormrod, \& Hamby, 2009). These youths are at increased risk for developing aggressive and antisocial behavior as well as other negative psychosocial outcomes (for reviews, see Fowler, Tompsett, Braciszewski, Jacques-Tiura, \& Baltes, 2009; Kitzmann, Gaylord, Holt, \& Kenny, 2003; Mazza \& Overstreet, 2000). Considerable progress has been made in identifying factors that may mediate these effects (for a review, see Hamby \& Grych, 2013). However, experiences with violence do not invariably lead to negative outcomes (e.g., DuMont, Widom, \& Czaja, 2007; Grogan-Kaylor, Ruffolo, Ortega, \& Clarke, 2008; Herrenkohl, 2011; McGloin \& Widom, 2001), and to more fully understand how exposure to violence affects children it is important to identify protective factors that serve to moderate or buffer its impact. Further, understanding the mechanisms by which protective factors operate has critical implications both for theory and for enhancing the effectiveness of prevention and intervention programs.

One way that protective factors could function is by interrupting the mediating processes that lead to aggression. Few studies have investigated this possibility, but DeBoard-Lucas, Fosco, Raynor, and Grych (2010) showed that qualities of parent-child relationships reduced children's appraisals of self-blame for interparental conflict, which in turn mediated the association between conflict and child maladjustment. The purpose of the present study was to test whether a proposed protective factor-secure parent-child attachmentreduced the association between witnessing violence and youths' beliefs about the justifiability of aggression and to test these beliefs as a mediator between violence exposure and aggressive behaviors. We focused on aggressive attitudes because conceptual models of the 
effects of exposure to diverse forms of violence emphasize the role of cognitive processes, proposing that observing violence leads to the development of beliefs that aggression is acceptable, normative, or effective, which in turn facilitate aggressive behavior (e.g., Bandura, 1986; Huesmann, 1988). Empirical studies consistently have supported these kinds of cognitions as mediators of the relationship between exposure to violence and aggressive behavior in childhood and adolescence (e.g., Bradshaw, Rodgers, Ghandour, \& Garbarino, 2009; Guerra, Huesmann, \& Spindler, 2003; Kinsfogel \& Grych, 2004). Identifying factors that influence children's aggressive attitudes thus may provide insight into the processes that lead to aggressive behavior and suggest strategies for reducing the adverse impact of exposure to violence on child adjustment.

Perceptions of the justifiability of aggression are likely to be influenced by other kinds of experiences in addition to violent interactions. In particular, relationships with caregivers have pervasive effects on children's social development, including their perceptions, beliefs, and expectations about relationships. Attachment theory holds that sensitive, responsive, and reliable caregiving promotes secure attachment and provides a foundation for children's long-term social and emotional development (Bowlby, 1969). Securely attached children develop beliefs (working models) that others are trustworthy and caring, which in turn shape their expectations for relationships and promote empathy and concern for others. Youths with secure working models would be expected to value themselves and others and to perceive hurting other people as unacceptable. Thus, supportive relationships with caregivers may counteract the negative effects of observing and experiencing violence.

Several studies have shown that parent-child and family relationships buffer the effects of different forms of violence on child functioning (e.g., Benhorin \& McMahon, 2008; Collishaw et al., 2007; Gorman-Smith, Henry, \& Tolan, 2004; Li, Nussbaum, \& Richards, 2007; Sousa et al., 2011). For example, Skopp, McDonald, Jouriles, and Rosenfield (2007) found that intimate partner violence was positively related to externalizing behaviors when mothers were low in warmth, but not at higher levels of maternal warmth, and adolescents exposed to community violence whose families were higher in emotional cohesion, structure, and effective parenting practices were (Routledge) and permission has been granted for this version to appear in e-Publications@Marquette. Taylor \& Francis (Routledge) does not grant permission for this article to be further copied/distributed or hosted elsewhere without the express permission from Taylor \& Francis (Routledge). 
less likely to perpetrate violence than adolescents from families lower in these attributes (Gorman-Smith et al., 2004). These studies show that a supportive family can buffer the effects of violence exposure on aggressive behaviors but do not shed light on the mechanism underlying this protective process. The goal of the present study was to examine whether secure mother-child attachment predicts less accepting attitudes about aggression in the context of children's experiences with aggression in the home and in the community. We examined whether secure attachment uniquely predicted children's beliefs after accounting for their exposure to aggression, which Fergus and Zimmerman (2005) labeled a "compensatory effect" or moderated the association between exposure to aggression and their attitudes about the justifiability of aggressive behavior (a "protective effect"; Fergus \& Zimmerman, 2005). In addition, we tested a full moderatedmediation model to determine if secure attachment buffered the effects of violence on attitudes and if aggressive attitudes mediated the relationship between exposure to violence and aggressive behaviors.

\section{Method}

\section{Participants}

Participants were drawn from a larger study and included 148 children (38\% male, 62\% female) ages 9-14 years, with a mean age of 11.15 ( $S D=1.39$ ). We recruited through a grade school and limited the sample to children older than age 8 , because by this age youth have developed the cognitive ability to report reliably on their own thoughts, feelings, and behaviors (Fraser, 1996). The youth represented diverse ethnic backgrounds, including 50\% Latino, 22\% African American, 18\% Caucasian, and 10\% other, most of whom classified themselves as multi- or biracial. These participants were recruited from elementary and middle schools by sending letters home to parents that described the purpose of the study. Parents who expressed interest in participating in the study were contacted to schedule a time for their participation. 
NOT THE PUBLISHED VERSION; this is the author's final, peer-reviewed manuscript. The published version may be accessed by following the link in the citation at the bottom of the page.

\section{Procedure}

The majority of interviews were conducted at the end of the school day at the schools where the youth were recruited. When not feasible (e.g., due to parents' work schedule), participants were offered the option of completing the study in a university research laboratory. After the purpose of the study was described to mothers and children, mothers' informed consent and youths' assent was obtained. With their mother in a separate room, the children completed a series of questionnaires measuring interparental, parentchild, and community aggression, as well as parent-child attachment, and read and answered questions regarding three vignettes portraying aggressive interactions between two peers and two siblings. In addition, both children and their mothers completed measures of aggressive behaviors. The research assistants who administered the measures were graduate students in clinical psychology and advanced undergraduate psychology students. Both graduate and undergraduate students received extensive training in interviewing, including interviewing victims of abuse. Mothers received $\$ 30$ and youths received $\$ 10$ for their participation. All research methods were approved by the Marquette University Institutional Review Board.

\section{Measures}

\section{Acceptability of aggression}

Research on youths' attitudes about aggression typically uses questionnaires that inquire about the acceptability of aggressive behaviors without providing a context in which the behavior occurs (e.g., Huesmann \& Guerra, 1997; Lim \& Ang, 2009). However, the perceived justifiability of a behavior often depends on the context; in particular, the degree to which the individual is provoked is an important factor. For example, whereas hitting someone without reason generally is perceived as unacceptable, hitting someone in selfdefense is viewed by many as justifiable. Therefore we adapted a set of vignettes that had been created for a study of adult attitudes toward violence (Lane \& Knowles, 2000) that describe situations in which an interaction escalates from verbal expressions of hostility or mild physical aggression to more severe acts of physical aggression 
(see Table 1). The vignettes were adapted to portray situations more relevant to children, such as two classmates arguing after lunch. Two of the vignettes describe pairs of friends, and one vignette describes siblings. Eighty-nine percent of the participants had siblings, and those without siblings were included in all analyses (the results were fundamentally unchanged when participants without siblings were excluded from analyses). Participants were asked to rate how acceptable the act of aggression in each vignette was on a Likert scale ranging from 1 (not ok at all) to 7 (completely ok). Support for the validity of the vignettes used in this study is demonstrated by a significant correlation with a reliable and valid measure of more general views of acceptability of aggression $(r=.63, p<.01$; Normative Beliefs about Aggression Scale, Huesmann \& Guerra, 1997). Youths' responses on the peer and sibling vignettes were highly correlated (average $r=.63, p<.01$ ), indicating consistency in attitudes across the vignettes, and so responses were summed across vignettes to create a single score for perceived aggression.

\section{TABLE 1 Acceptability of Aggression Vignettes}

1. Peers Carl and John are classmates. John brought his new soccer ball to school one day, and was practicing with it at recess. Carl asked John if he could play with him and John said no. Carl said that John was being selfish, and John told him to get his own ball and walked away. When John was practicing, the ball went near Carl and he kicked it over the fence and into the street. John ran over to him and knocked him down to the ground.

2. Peers Rosy and Becky are classmates. One day they were talking together after lunch, and started arguing and yelling at each other. Becky started to walk away and Rosy cursed at her and yelled something insulting. Becky turned around and hit Rosy. Rosy hit her back. They started fighting and other kids had to pull them apart. Both had cuts and bruises.

3. Siblings Jack and Matt are brothers. One day after school, they were both playing in their neighborhood. After a few minutes of playing, Jack started teasing Matt and calling him mean names. Matt punched Jack in the stomach. Jack fell to the ground and started crying.

\section{Exposure to aggression}

Because different forms of violence tend to co-occur (Hamby \& Grych, 2013), we assessed children's direct experience of parent-child aggression, observations of verbal and physical aggression in the family, and exposure to community violence. 
The Parent-Child Conflict Tactics Scale (CTSPC; Straus et al., 1998) was used to assess youths' exposure to verbal and physical aggression from their parents. Participants responded to 15 questions regarding both their mothers and fathers, answering how often they experienced an act of verbal or physical aggression in the past year, such as how often their mom or dad "hit him/her with a fist." Their options included "once," "twice," "3-5 times," "6-10 times," "11-20 times," and "more than 20 times." The CTSPC has also demonstrated acceptable levels of reliability in previous studies $(a=.88$; Straus et al., 1998) and in the current sample $(a=.88)$. This measure also has displayed both construct and discriminant validity (Straus et al., 1998).

The Children's Perceptions of Interparental Conflict Scale (CPIC; Grych, Seid, \& Fincham, 1992) is a 48-item measure that assesses youth self-reports of exposure to interparental aggression. Participants answer "true," "sort of true," or "false" on the questions. Three factoranalytically derived subscales are included in the CPIC: Conflict Properties, Threat, and Self-Blame. Only the Conflict Properties subscale was used in this study, because it assesses the frequency, intensity, and resolution of interparental conflict and includes questions such as "My parents have pushed or shoved each other during an argument." Higher scores on this measure indicate that conflict is more frequent, intense, and poorly resolved. This subscale has been shown to display good internal consistency, test-retest reliability, and convergent validity (Grych et al., 1992). Internal consistency of the CPIC in the present study was also strong $(a=.90)$.

Exposure to community violence was assessed using nine items from the Chicago Youth Development Study Stress Measure (Tolan \& Gorman-Smith, 1991). Children indicated how many times in the previous year they experienced each of a series of violent events, such as "I witnessed a violent crime." Internal reliability for this measure has been found acceptable ( $a=.67$; Tolan \& Gorman-Smith, 1991) and was acceptable in the present sample $(a=.68)$.

\section{Parent-child attachment}

Children's reports of parent-child attachment were assessed with the Security Scale (Kerns, Klepac, \& Cole, 1996). Designed for 
elementary school and middle school aged children, this 15-item measure assesses the belief that an attachment figure is responsive and available and the tendency to rely on and communicate with the attachment figure in times of stress (Granot \& Mayseless, 2001). Respondents read a statement, such as "Some kids find it easy to trust their mom BUT other kids are not sure if they can trust their mom" and chose which statement was most characteristic of them. The 4point items were summed to form an attachment security score, with higher scores indicating more secure relationships. Fathers were invited to participate in the study; however, due to the small number of father participants, father-child attachment was not included in the analyses. The Security Scale has displayed strong internal consistency (Cronbach's a $=0.84$ ), as well as strong convergent and divergent validity (Kerns et al., 1996). Strong internal consistency was found in the current sample as well, with a Cronbach's alpha of 0.82 .

\section{Aggressive behaviors}

Mother- and child-report of aggressive behaviors were assessed with the Achenbach (1991) Child Behavior Checklist for Ages 6-18 and Youth Self-Report Form, Aggressive Behaviors subscale. These 17-item (for children) and 18-item (for mothers) measures are widely used and demonstrate strong reliability and validity (for a review, see Achenbach \& Rescorla, 2001). In the current sample, the Child Behavior Checklist for Ages 6-18 and Youth Self-Report Form displayed good internal reliability $(a=0.89$ and $a=0.85$, respectively). To utilize both respondents' reports of aggressive behaviors, $z$ scores were created for child- and mother-report and combined for an overall aggression score; higher scores represent more aggressive behaviors.

\section{RESULTS}

\section{Descriptive Analyses}

Means and standard deviations for the exposure to violence, perceived acceptability of aggression, attachment, and aggressive behaviors variables, along with the correlations among them, are presented in Table 2. Youths' experiences of interparental aggression 
(CPIC) and parent-child aggression (CTSPC) were significantly related, as were parent-child aggression and exposure to community violence, but interparental aggression and community violence were not correlated. Both mother-child aggression and community violence were significantly related to youths' perceived acceptability of aggression in peer and sibling interactions, but interparental aggression was not. Maternal attachment was significantly related to parent-child aggression, community violence, and perceived acceptability of aggression, but its association with interparental aggression was marginally significant. Aggressive behaviors were positively related to exposure to aggression and aggressive beliefs and were negatively associated with maternal attachment.

TABLE 2

Descriptive and Cocrelationel Stasstics

\begin{tabular}{|c|c|c|c|c|c|c|}
\hline Variables & 1 & 2 & 8 & 4 & 3 & 6 \\
\hline \multicolumn{7}{|l|}{ 1. Parent Child Aggression } \\
\hline 2. Interpatental Azeression & $.42^{* 0}$ & & & & & \\
\hline 3. Community Agzression & $20^{\circ}$ & .04 & & & & \\
\hline 4. Aeseptahility of Aggression & $23 * *$ & 02 & $22^{* *}$ & & & \\
\hline 5. Aggressive Betaviots & $53^{*}$ & $.28^{*+}$ & $.23 *$ & $19^{*}$ & & \\
\hline 6. Attachument & $-24 *$ & $-.17 \pi$ & -.20 & $-27 *$ & $-26 *$ & \\
\hline $7, M$ & 32.39 & 11.90 & 1.92 & 6.43 & 05 & 4988 \\
\hline 8. $S D$ & 24.72 & 7,70 & 2.83 & 3.80 & 9.06 & 7.49 \\
\hline
\end{tabular}

Nole: Variables were assossod kasing a sum of the items in the CTSPC (patent child aggression), Conflict Properties subscale of the CMC (inter-

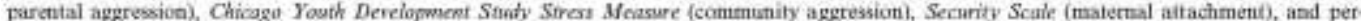
ceived agzressiob was assessed using a sum of participants' responses to all three of the vignettes portraying aggression. Aggressive behaviors was created by summing $z$-scotes for mother and thild-report of aggression. ${ }^{t} p<.06, * p<.05, * p<01$

\section{Relations Among Different Forms of Violence and}

\section{Aggressive Attitudes}

To test whether participants exposed to more aggression in the home and community would view aggression as more acceptable, a hierarchical multiple regression analysis was conducted. Age and gender were correlated with aggressive beliefs such that males reported more accepting attitudes toward aggression than females, and older youths indicated more accepting attitudes toward aggression than younger children. Thus, age and gender were included as covariates in the first step of the regression analysis. Youths' reported levels of exposure to different forms of aggression were included as the predictor variables, and their perceptions of the acceptability of aggression in the vignettes was the dependent variable. Together, reports of parent-child, interparental, and community aggression significantly predicted higher levels of perceived acceptability of 
aggression. The total variance of youths' perceptions of the peer and sibling vignettes explained by the model was $12.1 \%$. Youth reports of parent-child aggression were the only unique predictor of aggressive attitudes. Results are displayed in Table 3.

TABLE 3

Multiple Regression Analyses for Variables Predicting Youths' Perceived Acceptability of Aggression

\begin{tabular}{|c|c|c|c|}
\hline \multirow[b]{2}{*}{ Variable } & \multicolumn{3}{|c|}{ Perceived Acceptability of Aggression } \\
\hline & $B$ & $S E B$ & $\beta$ \\
\hline \multicolumn{4}{|l|}{ Step 1} \\
\hline Age & .36 & .23 & .13 \\
\hline Gender & -.60 & .68 & -.08 \\
\hline \multicolumn{4}{|l|}{ Step 2} \\
\hline Parent Child Aggression & .03 & .02 & $.22^{*}$ \\
\hline Interparental Aggression & -.04 & .05 & -.08 \\
\hline Community Aggression & .20 & .12 & .15 \\
\hline$R^{2}$ & & .11 & \\
\hline$F$ & & $3.32^{* *}$ & \\
\hline
\end{tabular}

Note: Age and gender of the participants was entered in the first two steps of the multiple regression; parent child, interparental, and community aggression were entered together in the third step of the multiple regression. $N=148$.

${ }^{*} p<.05 .{ }^{* *} p<.01$.

\section{Testing Maternal Attachment as a Moderator}

Hierarchical multiple regression analyses were used to test the hypotheses that youths' attachment to a caregiver would uniquely predict and/or moderate the relationship between their exposure to violence and attitudes about aggression (Table 4). To preserve power, each type of aggression and its interaction with attachment were entered in a separate hierarchical regression analysis. Youths' age and gender were entered as covariates in the first step and participants' exposure to each type of aggression (parent-child, interparental, or community) and maternal attachment in a second. An interaction term, created by centering and then multiplying scores of the predictor variables, was entered in the third step of the regression analyses. 
NOT THE PUBLISHED VERSION; this is the author's final, peer-reviewed manuscript. The published version may be accessed by following the link in the citation at the bottom of the page.

TABLE 4

Hierarchical Regression Analyses for Maternal Attachment as a Moderator Between Aggression and Perceived Acceptability of Aggression

\begin{tabular}{|c|c|c|c|}
\hline \multirow[b]{2}{*}{ Variable } & \multicolumn{3}{|c|}{ Perceived Acceptability of Aggression } \\
\hline & $\begin{array}{c}\text { Interparental } \\
\beta\end{array}$ & $\begin{array}{c}\text { Parent Child } \\
\beta\end{array}$ & $\begin{array}{c}\text { Community } \\
B\end{array}$ \\
\hline \multicolumn{4}{|l|}{ Step 1} \\
\hline Age & $.17^{*}$ & $.16^{*}$ & $.14^{+}$ \\
\hline Gender & $-.18^{*}$ & $-.17^{*}$ & $-.15^{*}$ \\
\hline \multicolumn{4}{|l|}{ Step 2} \\
\hline Attachment & $-.20^{*}$ & $-.16^{+}$ & -.07 \\
\hline \multicolumn{4}{|l|}{ Step 3} \\
\hline Aggression & -.02 & -.02 & .11 \\
\hline \multicolumn{4}{|l|}{ Step 4} \\
\hline Interaction & .14 & -.13 & $-.35^{* *}$ \\
\hline$R^{2}$ & .13 & .13 & .25 \\
\hline$F$ & $3.83^{* *}$ & $3.92^{* *}$ & $8.90^{* *}$ \\
\hline
\end{tabular}

Note: Aggression refers to interparental, parent child, and community aggression. The results of analyses for these different types of aggression are portrayed across the three columns. The attachment and aggression variables were centered by subtracting the variable mean from each variable's sum. The interaction term was created by multiplying the centered attachment and centered aggression variables. $N=148$. Attachment $=$ maternal attachment security.

${ }^{*} p<.05$. ${ }^{* *} p<.01$.

For the analysis involving interparental aggression, youths with more secure attachment to their mothers reported significantly less accepting attitudes toward aggression, but neither interparental aggression nor the interaction of attachment security and interparental aggression were significantly related to aggressive attitudes. For the analysis involving parent-child aggression, attachment was a marginally significant predictor, but neither parent-child aggression nor the interaction of attachment security and parent-child aggression accounted for significant unique variance. For the analysis of community violence, neither maternal attachment nor community violence were significant predictors, but the interaction of maternal attachment and community violence was significant, indicating (Routledge) and permission has been granted for this version to appear in e-Publications@Marquette. Taylor \& Francis (Routledge) does not grant permission for this article to be further copied/distributed or hosted elsewhere without the express permission from Taylor \& Francis (Routledge). 
maternal attachment moderated the association between community violence and youths' beliefs about aggression. This interaction, portrayed graphically in Figure 1, was explored by dividing participants into high- and low-attachment security groups (defined as 1 standard deviation above and below the mean) and conducting two multiple regression analyses in which exposure to community violence predicted attitudes about aggression with each of these groups (Aiken \& West, 1991). This analysis revealed that for youths with less secure attachment, exposure to greater community violence was related to more accepting attitudes about violence. In contrast, for youths with more secure attachment, exposure to greater community violence was unrelated to acceptance of peer and sibling violence.

FIGURE 1 Moderation of maternal attachment security on community violence predicting youths' perceptions of the acceptability of aggression.

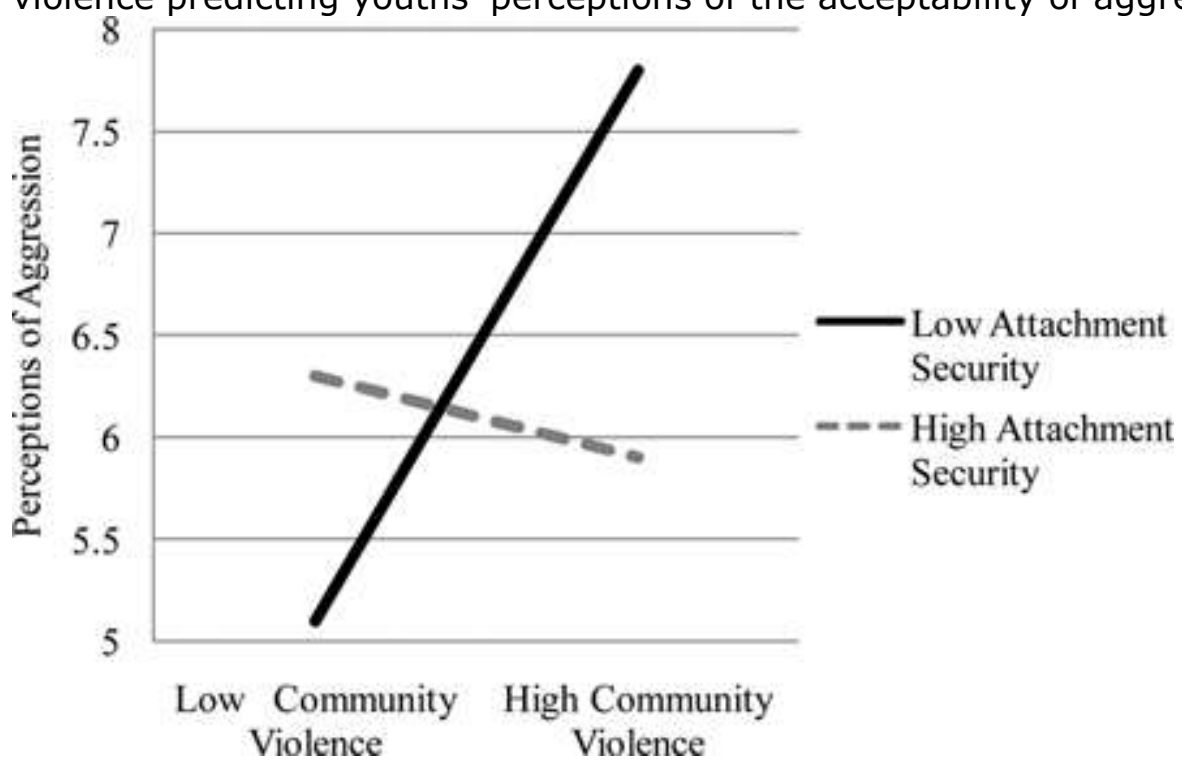

Testing the Full Moderated-Mediation Model

Expanding on the regression analyses, the significant moderation effect of maternal attachment was explored in a moderated-mediation model, with aggressive attitudes mediating the effect of community violence on aggressive behaviors. The moderatedmediation model was computed using the maximum likelihood approach in Amos 6.0 (Arbuckle, 2005). Consistent with T. J. B. Kline and Dunn's (2000) recommendations, the interaction term for community aggression and maternal attachment was created by

Journal of Clinical Child \& Adolescent Psychology, Vol 45, No. 5 (2016): pg. 605-613. DOI. This article is (C) Taylor \& Francis (Routledge) and permission has been granted for this version to appear in e-Publications@Marquette. Taylor \& Francis (Routledge) does not grant permission for this article to be further copied/distributed or hosted elsewhere without the express permission from Taylor \& Francis (Routledge). 
multiplying these centered predictor variables; however, when testing the model, uncentered main effect variables were used. Community violence, maternal attachment, and the interaction term were included as predictors of aggressive attitudes. After accounting for the relationship between community violence and aggressive behaviors, a path between aggressive attitudes and aggressive behaviors was included in the model. Age and gender also were added as predictors of aggressive behaviors to account for variation in these individual characteristics. Model fit was assessed using several indices, including nonsignificant chi-square tests, $\mathrm{x}^{2} / d f$ ratios of less than 3 (Arbuckle, 2005), Comparative fit index (CFI) values of greater than .90, and root mean square error of approximation (RMSEA) values less than .08 ( $R$. B. Kline, 2005).

The moderated-mediation model displayed good fit, $\mathrm{X}^{2}(10)=16.73, p>.05 ; \mathrm{X}^{2} / d f=1.67 ;$ CFI $=.90 ;$ RMSEA $=.07$. More important, maternal attachment significantly moderated the relation between exposure to community violence and aggressive attitudes ( $\beta=-.37, p<.001)$. Aggressive attitudes, in turn, predicted aggressive behaviors $(\beta=.68, p<.01)$. Using Baron and Kenny's (1986) approach to determining mediation effects, a significant mediation was supported in the model. The initial significant effect of community violence on aggressive behaviors $(\beta=.22, p=.01)$ became nonsignificant when the mediator (aggressive attitudes) was added to the model $(\beta=.07, p>.05)$; thus, aggressive attitudes mediated the effect of community violence on aggressive behaviors. The moderated mediation model is portrayed in Figure 2.

FIGURE 2 Path model testing attachment security in a moderated mediated relationship, including aggressive attitudes as the mediator between community violence and aggressive behaviors. Note: The aggressive behaviors outcome variable was created by combining z-scores for mother- and child-reported aggressive behaviors. Paths represented by solid lines are statistically significant at $p<.05$. 
NOT THE PUBLISHED VERSION; this is the author's final, peer-reviewed manuscript. The published version may be accessed by following the link in the citation at the bottom of the page.

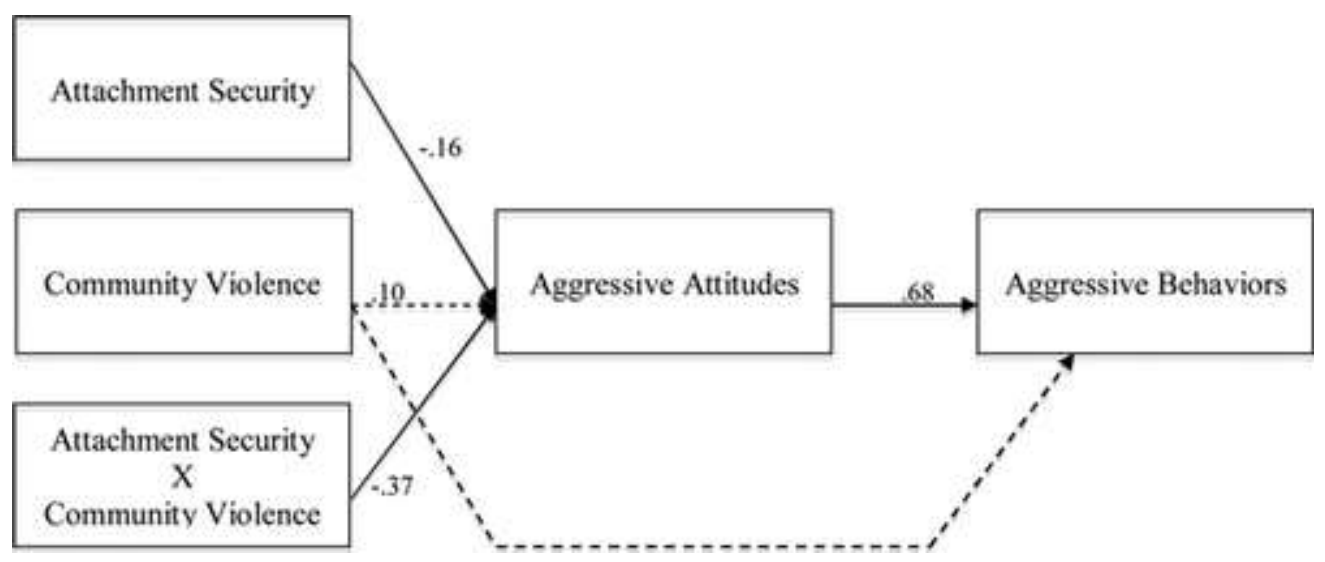

\section{Discussion}

The present study examined how experiences in and outside of the home may shape children's attitudes about the acceptability of aggression and how aggressive attitudes impact aggressive behaviors in violence-exposed children. Given that aggressive attitudes have been established as a mediator of the association between exposure to violence and perpetrating aggressive and violent behavior, both in previous studies (e.g., Guerra et al., 2003; McMahon, Felix, Halpert, \& Petropoulos, 2009) and in the current study, identifying factors that can reduce the impact of violence on youths' attitudes is an important step in understanding and reducing the effects of violence. This study focused on attachment security because the working models associated with secure attachment may counteract the tendency for witnesses of aggression to view it as normative or acceptable. Individuals with secure working models view the self and others as worthy and valuable and thus may be less likely to believe that engaging in aggression is justifiable.

We examined the relative predictive power of aggression occurring in three contexts (between parents, between parents and children, and in the community) and found that exposure to parentchild aggression contributed uniquely to perceiving aggression in sibling and peer interactions as more acceptable. In contrast, children with more secure attachment to their mothers reported less accepting attitudes toward aggression. The importance of parent-child relationships in shaping children's attitudes about aggression was demonstrated in analyses showing that the significant association 
between parent-child aggression and aggressive attitudes became nonsignificant when attachment quality was added to the equation, whereas attachment quality continued to uniquely predict attitudes. These results support a "compensatory effect" for attachment on the association of exposure to aggression and aggressive attitudes. Further, parents who engage in more aggression are unlikely to consistently engage in the kind of interactions that promote empathy and concern for others, which can consequently undermine the potential benefits of attachment quality.

In addition, attachment moderated the association between exposure to community violence and aggressive attitudes: Whereas youths with less secure maternal attachments showed increasingly accepting attitudes toward aggression when exposed to more community violence, and for children with more secure attachment, exposure to community violence was not associated with more accepting attitudes of aggression. This effect also was observed the full moderated-mediation model, in which attachment security buffered the effect of community violence on perceived acceptability of aggression, and these aggressive attitudes mediated the effect of community violence on aggressive behaviors. The model fit well and supported the conclusion that having a secure attachment generally decreased children's belief that aggression is acceptable, which in turn decreased aggressive behaviors in youths exposed to community violence. Thus, having a close and supportive relationship with a caregiver appears to interrupt or reduce the tendency for children who witness violence in the community to develop beliefs that aggressing against others is justifiable, suggesting a "protective effect," and these less aggressive attitudes decrease engaging in aggressive behaviors. These results are consistent with previous studies supporting the quality of the mother-child relationship as a protective factor for youth exposed to community violence and suggest a mechanism by which the protective effect occurs (Gorman-Smith et al., 2004; Skopp et al., 2007). Secure parent-child relationships provide an alternative to violent interactions witnessed in the community, and the working models that arise from a secure attachment relationship may counteract the effects of witnessing violence outside of the home on children's beliefs about the acceptability or justifiability of aggressive behavior and on their aggressive behaviors. 
However, the mother-child attachment did not act as a buffer when aggression occurred in the home. Whereas a secure parent-child relationship provides an alternative model for relationships than violent interactions witnessed in the community, when parents act aggressively or abusively toward their children or each other they are unlikely to consistently engage in the kind of interactions that promote empathy and concern for others. Indeed, attachment security was negatively correlated with parent-child and interparental aggression. The importance of parent-child relationships in shaping children's attitudes about aggression also was demonstrated in the analyses showing that the significant association between parent-child aggression and aggressive attitudes became nonsignificant when attachment quality was added to the equation.

\section{Limitations}

The cross-sectional design of the study limits the ability to draw causal inferences; future research should utilize longitudinal methods to establish a causal relationship between exposure to violence, attachment, and attitudes about aggression. Also, the majority of the sample consisted of children from racial/ethnic minority groups, and the results may not generalize to nonminority populations; examining youths from diverse backgrounds could offer insights into the generalizability of the results to different populations. The measure of attachment used in this study focused primarily on children having a secure base. It is unclear whether the results of this study are specific to the parent-child attachment or can be generalized to the parentchild relationship more broadly. The current study also focused solely on mother-child attachment security, and the protective function of the father-child relationship is less understood. Research on how children's relationship with their fathers affects their attitudes about aggression could further inform intervention and treatment for violence-exposed youth. Finally, the present sample reported relatively low levels of parent-child and interparental aggression, and it is possible that attachment quality may not offset the impact of witnessing violence in highly aggressive families.

Journal of Clinical Child \& Adolescent Psychology, Vol 45, No. 5 (2016): pg. 605-613. DOI. This article is (C) Taylor \& Francis (Routledge) and permission has been granted for this version to appear in e-Publications@Marquette. Taylor \& Francis (Routledge) does not grant permission for this article to be further copied/distributed or hosted elsewhere without the express permission from Taylor \& Francis (Routledge). 
NOT THE PUBLISHED VERSION; this is the author's final, peer-reviewed manuscript. The published version may be accessed by following the link in the citation at the bottom of the page.

\section{Implications}

Models of resilience (i.e., Fergus \& Zimmerman, 2005; Howard, Budge, \& McKay, 2010) highlight the importance of identifying factors that buffer or reduce the effects of risk factors on children. This study supports the role of the mother-child relationship as a protective factor that may reduce aggressive beliefs, which mediate the link between exposure to violence and aggressive behavior. It also suggests that strengthening this relationship could be effective in changing aggressive attitudes, which highlights the value of familyfocused interventions for children exposed to violence. Several treatments and interventions for children exposed to violence focus on the parent-child relationship, such as Child-Parent Psychotherapy (Lieberman, 2004) and Parent-Child Interaction Therapy (Chaffin et al., 2004). The results of the current study also support interventions that directly address youths' attitudes. For instance, in TraumaFocused Cognitive-Behavioral Therapy (Cohen \& Mannarino, 1993), children and their parents are taught to challenge maladaptive attitudes. This could be an important aspect to any treatment for youths exposed to violence. Given that not all children are fortunate enough to have warm and accepting caregivers, it may be that forming a supportive relationship with other important adults (e.g., teachers, coaches, neighbors) could also act to interrupt the development of aggressive attitudes and promote more adaptive functioning in violence-exposed youth. These kinds of interventions would be further strengthened by school-level and community-level interventions that target school climate and community violence.

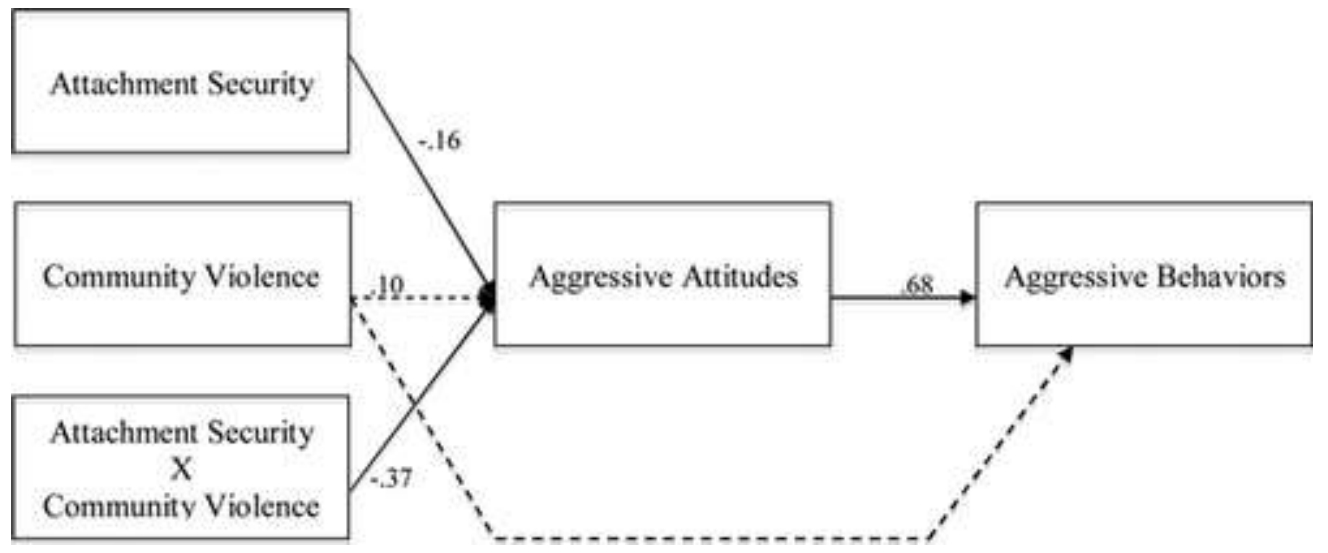

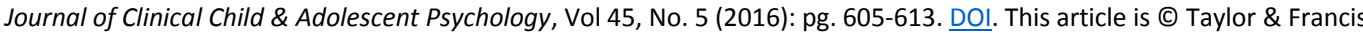
(Routledge) and permission has been granted for this version to appear in e-Publications@Marquette. Taylor \& Francis (Routledge) does not grant permission for this article to be further copied/distributed or hosted elsewhere without the express permission from Taylor \& Francis (Routledge). 


\section{References}

Achenbach, T. M. (1991). Child behavior checklist/4-18. Burlington, VT: University of Vermont.

Achenbach, T. M. \& Rescorla, L. (2001). ASEBA school-age forms \& profiles. Burlington, VT: Aseba.

Aiken, L. S. \& West, S. G. (1991). Multiple regression: Testing and interpreting interactions. Newbury Park, CA: Sage.

Arbuckle, J. L. (2005). Amos 6.0 [Computer software]. Chicago, IL: SPSS.

Bandura, A. (1986). Social foundations of thoughts and actions: A social cognitive theory. Engelwood Cliffs, NJ: Prentice Hall.

Baron, R. M. \& Kenny, D. A. (1986). The moderator-mediator variable distinction in social psychological research: Conceptual, strategic, and statistical considerations. Journal of Personality and Social Psychology, 51, 1173-1182. doi:10.1037/0022-3514.51.6.1173

Benhorin, S. \& McMahon, S. D. (2008). Exposure to violence and aggression: Protective roles of social support among urban African American youth. Journal of Community Psychology, 36, 723-743. doi: $10.1002 /$ jcop. 20252

Bowlby, J. (1969). Attachment and loss: Vol. 1. Attachment. New York, NY: Basic Books.

Bradshaw, C. P., Rodgers, C. R. R., Ghandour, L. A. \& Garbarino, J. (2009). Social-cognitive mediators of the association between community violence exposure and aggressive behavior. School Psychology Quarterly, 24, 199-210. doi:10.1037/a0017362

Chaffin, M., Silovsky, J. F., Funderburk, B., Valle, L. A., Brestan, E. V., Balachova, T., ... Bonner, B. L. (2004). Parent-child interaction therapy with physically abusive parents: Efficacy for reducing future abuse reports. Journal of Consulting and Clinical Psychology, 72, 500-510. doi:10.1037/0022-006X.72.3.500

Cohen, J. A. \& Mannarino, A. P. (1993). A treatment model for sexually abused preschools. Journal of Interpersonal Violence, 8, 115-131. doi: $10.1177 / 088626093008001009$

Collishaw, S., Pickles, A., Messer, J., Rutter, M., Shearer, C. \& Maughan, B. (2007). Resilience to adult psychopathology following childhood maltreatment: Evidence from a community sample. Child Abuse \& Neglect, 31, 211-229. doi:10.1016/j.chiabu.2007.02.004

DeBoard-Lucas, R. L., Fosco, G. M., Raynor, S. R. \& Grych, J. H. (2010). Interparental conflict in context: Exploring relations between parenting processes and children's conflict appraisals. Journal of Clinical Child \&

Journal of Clinical Child \& Adolescent Psychology, Vol 45, No. 5 (2016): pg. 605-613. DOI. This article is (c) Taylor \& Francis (Routledge) and permission has been granted for this version to appear in e-Publications@Marquette. Taylor \& Francis (Routledge) does not grant permission for this article to be further copied/distributed or hosted elsewhere without the express permission from Taylor \& Francis (Routledge). 
NOT THE PUBLISHED VERSION; this is the author's final, peer-reviewed manuscript. The published version may be

accessed by following the link in the citation at the bottom of the page.

Adolescent Psychology, 39, 163-175.

doi:10.1080/15374410903532593

DuMont, K. A., Widom, C. S. \& Czaja, S. J. (2007). Predictors of resilience in abused and neglected children grown-up: The role of individual and neighborhood characteristics. Child Abuse \& Neglect, 31, 255-274. doi: $10.1016 /$ j.chiabu.2005.11.015

Fergus, S. \& Zimmerman, M. A. (2005). Adolescent resilience: A framework for understanding healthy development in the face of risk. Annual Review of Public Health, 26, 399-419. doi:10.1146/annurev.publhealth.26.021304.144357

Finkelhor, D., Turner, H., Ormrod, R. \& Hamby, S. L. (2009). Violence, abuse, and crime exposure in a national sample of children and youth. Pediatrics, 124, 1411-1423. doi:10.1542/peds.2009-0467

Fowler, P. J., Tompsett, C. J., Braciszewski, J. M., Jacques-Tiura, A. J. \& Baltes, B. B. (2009). Community violence: A meta-analysis on the effect of exposure and mental health outcomes of children and adolescents. Development and Psychopathology, 21, 227-259. doi: $10.1017 /$ S0954579409000145

Fraser, M. W. (1996). Aggressive behavior in childhood and early adolescence: An ecological-developmental perspective on youth violence. Social Work, 41, 347-361.

Gorman-Smith, D., Henry, D. B. \& Tolan, P. H. (2004). Exposure to community violence and violence perpetration: The protective effects of family functioning. Journal of Clinical Child \& Adolescent Psychology, 33, 439-449. doi:10.1207/s15374424jccp3303_2

Granot, D. \& Mayseless, O. (2001). Attachment security and adjustment to school in middle childhood. International Journal of Behavioral Development, 25, 530-541. doi:10.1080/01650250042000366

Grogan-Kaylor, A., Ruffolo, M. C., Ortega, R. M. \& Clarke, J. (2008). Behaviors of youth involved in the child welfare system. Child Abuse \& Neglect, 32, 35-49. doi:10.1016/j.chiabu.2007.09.004

Grych, J. H., Seid, M. \& Fincham, F. D. (1992). Assessing marital conflict from the child's perspective: The children's perception of interparental conflict scale. Child Development, 63, 558-572. doi:10.2307/1131346

Guerra, N. G., Huesmann, L. R. \& Spindler, A. (2003). Community violence exposure, social cognition, and aggression among urban elementary school children. Child Development, 74, 1561-1576. doi: $10.1111 / 1467-8624.00623$

Hamby, S. L. \& Grych, J. H. (2013). The web of violence: Exploring connections among different forms of interpersonal violence and abuse. New York, NY: Springer.

Herrenkohl, T. I. (2011). Family violence and co-occurring risk factors for children exposed to violence. In T. I. Herrenkohl E. Aisenberg J. H.

Journal of Clinical Child \& Adolescent Psychology, Vol 45, No. 5 (2016): pg. 605-613. DOI. This article is (C) Taylor \& Francis (Routledge) and permission has been granted for this version to appear in e-Publications@Marquette. Taylor \& Francis (Routledge) does not grant permission for this article to be further copied/distributed or hosted elsewhere without the express permission from Taylor \& Francis (Routledge). 
Williams \& J. M. Jenson (Eds.), Violence in context: Current evidence on risk, protection, and prevention (pp. 92-108). New York, NY:

Oxford University Press.

Howard, K. A. S., Budge, S. L. \& McKay, K. M. (2010). Youth exposed to violence: The role of protective factors. Journal of Community Psychology, 38, 63-79. doi:10.1002/jcop.20352

Huesmann, L. R. (1988). An information processing model for the development of aggression. Aggressive Behavior, 14, 13-24. doi:10.1002/1098-2337(1988)14:1<13: :aidab2480140104> 3.0.co;2-j

Huesmann, L. R. \& Guerra, N. G. (1997). Children's normative beliefs about aggression and aggressive behavior. Journal of Personality and Social Psychology, 72, 408-419. doi:10.1037/0022-3514.72.2.408

Kerns, K. A., Klepac, L. \& Cole, A. (1996). Peer relationships and preadolescents' perceptions of security in the child-mother relationship. Developmental Psychology, 32, 457-466. doi: $10.1037 / 0012-1649.32 .3 .457$

Kinsfogel, K. M. \& Grych, J. H. (2004). Interparental conflict and adolescent dating relationships: Integrating cognitive, emotional, and peer influences. Journal of Family Psychology, 18, 505-515. doi: $10.1037 / 0893-3200.18 .3 .505$

Kitzmann, K. M., Gaylord, N. K., Holt, A. R. \& Kenny, E. D. (2003). Child witnesses to domestic violence: A meta-analytic review. Journal of Consulting and Clinical Psychology, 71, 339-352. doi:10.1037/0022006X.71.2.339

Kline, R. B. (2005). Principles and practice of structural equation modeling (2nd ed.). New York, NY: Guilford.

Kline, T. J. B. \& Dunn, B. (2000). Analysis of interaction terms in structural equation models: A non-technical demonstration using the deviation score approach. Canadian Journal of Behavioural Science, 32, 127132. doi: $10.1037 / \mathrm{h} 0087107$

Lane, B. \& Knowles, A. (2000). Community attitudes to domestic violence: Attributions of responsibility, and suggested punishments related to alcohol consumption and level of violence. Psychiatry, Psychology, and Law, 7, 51-58. doi:10.1080/13218710009524970

Li, S. T., Nussbaum, K. M. \& Richards, M. H. (2007). Risk and protective factors for urban African-American youth. American Journal of Community Psychology, 39, 21-35. doi:10.1007/s10464-007-9088-1

Lieberman, A. F. (2004). Traumatic stress and quality of attachment: Reality and internalization in disorders of infant mental health. Infant Mental Health Journal, 25, 336-351. doi:10.1002/imhj.20009

Journal of Clinical Child \& Adolescent Psychology, Vol 45, No. 5 (2016): pg. 605-613. DOI. This article is (C) Taylor \& Francis (Routledge) and permission has been granted for this version to appear in e-Publications@Marquette. Taylor \& Francis (Routledge) does not grant permission for this article to be further copied/distributed or hosted elsewhere without the express permission from Taylor \& Francis (Routledge). 
Lim, S. H. \& Ang, R. P. (2009). Relationship between boys' normative beliefs about aggression and their physical, verbal, and indirect aggressive behaviors. Adolescence, 44, 635-650.

Mazza, J. J. \& Overstreet, S. (2000). Children and adolescents exposed to community violence: A mental health perspective for school psychologists. School Psychology Review, 29, 86.

McGloin, J. M. \& Widom, C. S. (2001). Resilience among abused and neglected children grown up. Development and Psychopathology, 13, 1021-1038. doi:10.1017/S095457940100414X

McMahon, S. D., Felix, E. D., Halpert, J. A. \& Petropoulos, L. N. (2009). Community violence exposure and aggression among urban adolescents: Testing a cognitive mediator model. Journal of Community Psychology, 37, 895-910. doi:10.1002/jcop.20339

Skopp, N. A., McDonald, R., Jouriles, E. N. \& Rosenfield, D. (2007). Partner aggression and children's externalizing problems: Maternal and partner warmth as protective factors. Journal of Family Psychology, 21, 459467. doi:10.1037/0893-3200.21.3.459

Sousa, C., Herrenkohl, T. I., Moylan, C. A., Tajima, E. A., Klika, J. B., Herrenkohl, R. C. \& Russo, M. J. (2011). Longitudinal study on the effects of child abuse and children's exposure to domestic violence, parent-child attachments, and antisocial behavior in adolescence. Journal of Interpersonal Violence, 26, 111-136. doi:10.1177/0886260510362883

Straus, M. A., Hamby, S. L., Finkelhor, D., Moore, D. W. \& Runyan, D. (1998). Identification of child maltreatment with the parent-child conflict tactics scales: Development and psychometric data for a national sample of American parents. Child Abuse \& Neglect, 22, 249270. doi:10.1016/S0145-2134(97)00174-9

Tolan, P. H. \& Gorman-Smith, D. (1991). Chicago youth development study stress and coping interview manual. Chicago, IL: Institute for Juvenile Research, University of Illinois at Chicago.

Journal of Clinical Child \& Adolescent Psychology, Vol 45, No. 5 (2016): pg. 605-613. DOI. This article is (C) Taylor \& Francis (Routledge) and permission has been granted for this version to appear in e-Publications@Marquette. Taylor \& Francis (Routledge) does not grant permission for this article to be further copied/distributed or hosted elsewhere without the express permission from Taylor \& Francis (Routledge). 